\title{
Prevalence and Antimicrobial-Susceptibility Profiles of Salmonella in Smallhold Broiler Supply Chains in Central Ethiopia
}

\author{
Tesfaye Belachew' \\ Eyuel Mulusew ${ }^{2}$ \\ Yonas Tolosa ${ }^{2}$ \\ Zerihun Asefa ${ }^{3}$ \\ Haileleul Negussie ${ }^{4}$ \\ Teshale Sori $^{4}$ \\ 'Epidemiology Unit, Asella Regional \\ Veterinary Laboratory, Asella, Oromia \\ State, Ethiopia; ${ }^{2}$ Department of \\ Biomedical Sciences, College of \\ Veterinary Medicine and Agriculture, \\ Addis Ababa University, Bishoftu, Oromia \\ State, Ethiopia; ${ }^{3}$ Veterinary Teaching \\ Hospital, College of Veterinary Medicine \\ and Agriculture, Addis Ababa University, \\ Bishoftu, Oromia State, Ethiopia; \\ ${ }^{4}$ Department of Clinical Studies, College \\ of Veterinary Medicine and Agriculture, \\ Addis Ababa University, Bishoftu, Oromia \\ State, Ethiopia
}

\begin{abstract}
Purpose: Salmonellosis is a foodborne zoonoses found worldwide. The main purpose of this study was to isolate and identify Salmonella and assess their antimicrobial susceptibility profiles from smallhold broilers supply chains and slaughterhouses in Bishoftu and Modjo, central Ethiopia.
\end{abstract}

Methods: Four smallhold broiler farms under the auspices of Chico Meat were selected randomly. Feed, water, and water- and feed-trough samples were collected from broiler farms, while cecal contents were collected from slaughtered chicken at Chico Meat slaughterhouse. Conventional bacteriological techniques were used to isolate and identify Salmonella from the samples. Kirby-Bauer disk diffusion was employed to assess the antimicrobial susceptibility of the isolates.

Results: Salmonella was isolated from 131 (24.3\%, 95\% CI 20.74-28.15) of the 539 samples tested. Salmonella was found in 43 of the 250 samples collected from Bishoftu $(22 \%, 95 \%$ CI $17.02 \%-27.65 \%)$ and 76 of the 289 samples collected from Modjo $(26.29 \%$, $95 \%$ CI $21.32 \%-31.77 \%$ ). Salmonella was isolated from $26.46 \%$ of the cloacal samples, $21 \%$ of the cecal contents, $30.77 \%$ of the feed samples, $25 \%$ of the water samples, $22.22 \%$ of samples from feed troughs, and $20 \%$ of samples from water troughs. The highest level of resistance $(80.81 \%)$ was observed against tetracycline, followed by kanamycin $(71.72 \%)$, chloramphenicol and amoxicillin (67.68\%), sulfamethazole-trimethoprim (61.62\%), naldixic acid (63.64\%), and streptomycin (59.60\%), whereas most of the isolates were susceptible to gentamicin (69.70\%). Resistance to more than two drugs was also observed.

Conclusion: Salmonella was found in high prevalence in broilers, their feed, and their environment. Moreover, a majority of the isolates were resistant to most antimicrobials used in medical and poultry practices. This has significant implications for public health and antimicrobial resistance.

Keywords: antimicrobials, broilers, central Ethiopia, resistance, Salmonella, smallhold farms

\section{Introduction}

The broiler industry has huge potential to circumvent food and nutrition insecurity in developing countries. Salmonella has the capacity to adapt to changing environments and can develop resistance against routine sanitary practices, chemical disinfectants, and antibacterial drugs. ${ }^{1}$ The newly growing broiler sector in Ethiopia is confronting various infectious diseases, including Salmonella infection, ${ }^{2,3}$ which is transmitted vertically and results in decreased production.
Department of Clinical Studies, College of Veterinary Medicine and Agriculture, Addis Ababa University, P.O. Box 34, East Shewa Zone, Bishoftu, Oromia State, Ethiopia,

Tel +25। 9| 363-637

Email teshalesori2002@yahoo.com;

teshale.sori@aau.edu.et 
Common serotypes of Salmonella isolated from broilers are S. pullorum, S. gallinarum, S. infantis, S. typhimurium, and $S$. enteritidis. ${ }^{4}$ In broilers, Salmonella infection mostly results in pullorum disease or bacillary white diarrhea in chicks 2-3 weeks old, causing high mortality. Broiler chickens can acquire Salmonella from parent stock, feed, water, or the environment and serve as a reservoir for humans. $^{5}$

Salmonellosis remains one of the most frequent foodborne zoonoses, constituting a worldwide major public health concern, mainly due to consumption of poultry products, such as broiler meat. ${ }^{5,6}$ Although different serotypes have been associated with salmonellosis, S.enteritidis is the most frequent in the EU and US, followed by S. typhimurium. S. enteritidis is commonly associated with poultry and poultry products, while $S$. typhimurium is less commonly associated with poultry. Foods of animal origin, in particular contaminated poultry products (eggs and meat) are considered the main vehicles of Salmonella infection and are clearly associated with the worldwide epidemic of S. enteritidis. Diverse epidemiological studies have also supported a considerable contribution of poultry foodstuffs to the salmonellosis burden. ${ }^{6}$

Antimicrobials have been utilized for a long time in broiler practices, both for growth promotion and control of infections. However, such use has been associated with the development of resistance by bacteria. Resistance to various antimicrobials by Salmonella has been reported in Pakistan, ${ }^{7}$ Ghana, ${ }^{8}$ and Ethiopia. ${ }^{9}$ The misuse of antimicrobials in humans and animals has led to an increase in the number of multidrug-resistant bacterial strains, which has been identified by WHO and health authorities as a global public health and veterinary concern. ${ }^{10}$ The number of antimicrobial-resistant Salmonella strains isolated from human cases has been linked to the widespread use of antimicrobial agents in food-animal practices. ${ }^{11}$ The widespread occurrence of antimicrobial-resistant Salmonella in increased morbidity and mortality and costs of treatment. This has social and economic consequences, necessitating the need for ongoing monitoring of the emergence of antimicrobial resistance in Salmonella spp. ${ }^{11}$

In Ethiopia during the last few years, there has been a gradual increase in poultry multiplication and distribution centers, along with smallhold broiler farms. ${ }^{12}$ Studies have revealed widespread occurrence of Salmonella in chicken, cattle, camels, sheep, goats, humans, foodstuffs, and the environment. ${ }^{13,14}$ Resistance to various antimicrobials has been reported in Salmonella isolated from beef ${ }^{15}$ and milk. ${ }^{16}$ Since broiler meat is the secondmost popular meat in the world, accounting for around $36 \%$ of total meat production, ${ }^{17}$ there is a dire need to develop better understanding and assist poultry stakeholders to reduce Salmonella and delay development of resistance to antimicrobials. Routine bacteriological monitoring of feed, water, and broilers and their products is needed to safeguard public health and improve meat production. It is also important to regularly monitor the development of resistance to antimicrobials by Salmonella in order to efficiently treat Salmonella infections in humans. This study was conducted with the objectives of isolation and identification of Salmonella from smallhold broilers chickens, their inputs and environs, and assessment of the antimicrobial profiles of isolates in the towns of Bishoftu and Modjo in central Ethiopia.

\section{Methods \\ Study Areas}

Bishoftu is located in Oromia Regional State, Ethiopia, approximately $47 \mathrm{~km}$ southeast of Addis Ababa (Figure 1). Its topography is undulating, with flatland to the north and east of the town, which is surrounded by many lakes, and hills to the south. The total land area of the town is about $15,273 \mathrm{ha}$, and it lies at an altitude of 1,900-1,995 $\mathrm{m}$ above sea level. It has well-developed poultry and dairy enterprises. Modjo (also spelled Mojo) is in central Ethiopia, and takes its name from the nearby river. Located in East Shewa Zone of Oromia, its elevation is 1,788-1,$825 \mathrm{~m}$ above sea level, and it is about $64 \mathrm{~km}$ southeast of Addis Ababa. There are several smallhold and a few commercial poultry farms in the town.

\section{Description of Farms and Chico Meat Slaughterhouse}

The samples (cloacal swabs, samples from water and feed troughs, feed and water samples) considered for isolation of Salmonella were collected from smallhold broiler farms located in Bishoftu and Modjo, and cecum contents were collected from chicken slaughtered at Chico Meat slaughterhouse in Bishoftu. Established by Jacobs's Integrated Farm, Chico Meat distributes day-old broiler chickens to smallhold farmers in Bishoftu, Modjo, and Adama. These smallhold farms serve as out-growers and supply the broilers to the slaughterhouse in Bishoftu. The farmers are provided with day-old chickens, feed, and other inputs, 


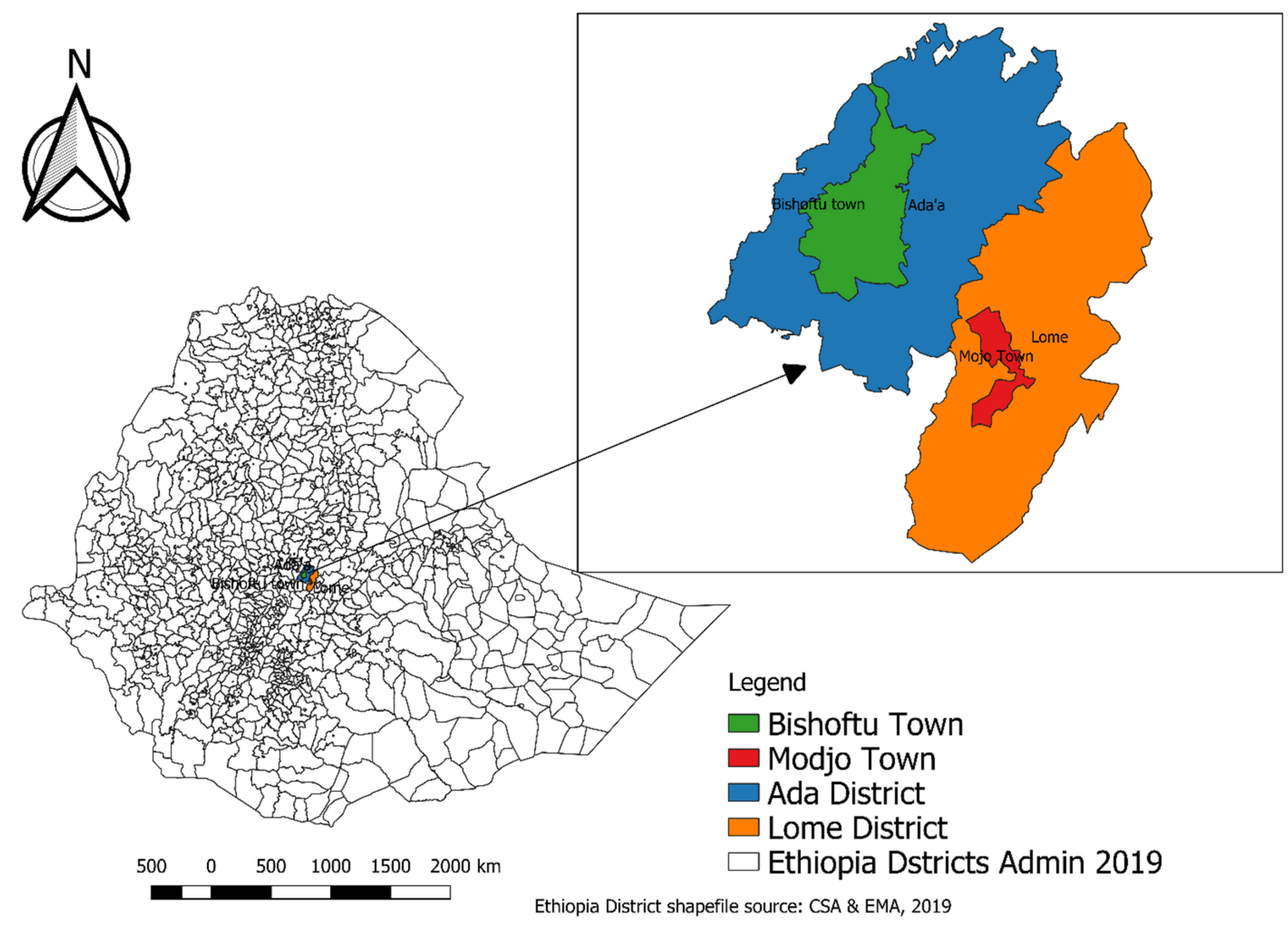

Figure I Map of Ethiopia depicting the study areas.

Notes: This map was developed from Ethiopian district administrative shape files 2019 using QGIS version 3.2.I, 2020.

which are discounted when the chickens are provided to the Chico Meat slaughterhouse. The farmers use management practices directed by the Chico Meat team, and all of them provide the finished chicken to the slaughterhouse. Chico Meat is a modern slaughterhouse with a processing capacity of $22,500 \mathrm{~kg}$ a day or 15,000 chickens a week. It has established links with local restaurants, hotels, supermarkets, resorts, and other retailers in all parts of Ethiopia. Chico Meat distributes Ross 308, Hubbard classic, and Cobb 500 broiler chickens imported from Belgium and Germany to out-growers. The smallhold farms or outgrowers keep broiler chickens numbering 500-2,500 chickens for 35-45 days.

\section{Study Design and Samples}

This was a cross-sectional study. Bishoftu and Modjo were selected because the out-growers supplied with day-old chickens were mostly situated in these two towns, where are ten out-grower or smallhold broiler farms under the auspices of Chico Meat. From those farms, four were randomly selected using a lottery system. Two farms, designated $\mathrm{B} 1$ and $\mathrm{B} 2$, were selected randomly from Bishoftu, and two, M1 and M2, from Modjo. A total of 539 samples comprising 189 cloacal samples, 52 feed samples, 48 water samples, 60 samples from water troughs, and 90 samples from feed troughs were collected. In addition, 100 cecal contents were collected from 100 chickens slaughtered at Chico Meat. The chickens sampled at slaughter house were randomly selected from those supplied to the slaughterhouse. From each of the farms selected from Bishoftu, cloacal swab samples were collected from 50 chickens. From farm B1, 14 feed samples of about $5 \mathrm{~g}$ each and eleven water samples were collected. From farm B2, 16 feed samples and nine water samples were collected. In addition, ten and 40 samples were collected from water and feed troughs, respectively. From the two farms selected from Modjo, 89 cloacal samples (44 from farm M1 and 45 from farm M2) were 
collected. Eleven feed samples and 14 water samples were collected from each of the selected farms. Fifty samples were collected from each of water and feed troughs. Also, 25 chickens were randomly selected at Chico Meat from each of the four farms studied, and their cecal contents were collected for isolation and identification of Salmonella.

\section{Sampling Method}

Both wings of the broiler chickens were held with one hand, keeping the animal's heads down so as to expose the caudal parts of the chicken. Before collection of samples, the surface of the cloaca was disinfected using 70\% alcohol for 2 minutes. A sterile cotton swab was moistened with buffered peptone water, inserted into the cloacae, and rolled inside several times. The swabs were immediately transferred to universal bottles containing $10 \mathrm{~mL}$ buffered peptone water and kept in an icebox. Approximately 10$15 \mathrm{~g}$ feed was collected into a universal tube. Feed samples were collected before being provided to the chickens. These samples were collected into sterile plastic bags and kept in an icebox. Similarly, $5 \mathrm{~mL}$ water was collected from each source (tap water versus tank water) into sterile bottles and kept in an icebox. Swab samples were also collected from feed and water troughs before any feed and water were blended. In the slaughter house, about 1-1.5 g cecal contents were squeezed into sterile universal bottles, each containing $10 \mathrm{~mL}$ buffered peptone water, ${ }^{18}$ and placed in an icebox. All samples were individually labeled, placed in separate plastic bags, transferred into a sterile icebox and transported to the Microbiology Laboratory, College of Veterinary Medicine and Agriculture, Addis Ababa University for isolation of Salmonella.

\section{Isolation of Salmonella}

Isolation of Salmonella was conducted using the bacteriological methods described for detection and isolation of Salmonella in ISO guidelines. ${ }^{19}$ Briefly, samples were incubated at $37^{\circ} \mathrm{C}$ for $18-24$ hours in buffered peptone water and nutrient broth to allow suscitation of Salmonella prior to transferral into selective enrichment media. ${ }^{20}$ Rappaport-Vassiliadis medium with soya broth was inoculated with samples from pre-enrichment medium and incubated at $37.5^{\circ} \pm 1^{\circ} \mathrm{C}$ for $24 \pm 3$ hours. ${ }^{21}$ Bacteria that grew on enriched media were plated onto Salmonella-Shigella (SS) agar. First, samples from enriched medium were plated onto SS agar, incubated at $37^{\circ} \mathrm{C} \pm 1^{\circ} \mathrm{C}$ for $18-24$ hours, and examined for the presence of suspected Salmonella colonies. Pure Salmonella colonies from SS agar were subcultured onto XLD agar and BGA.

\section{Identification of Salmonella}

Identification of Salmonella was done by both microscopic examination of stained smears from typical colonies ${ }^{22}$ and standard biochemical tests, such as triple sugar iron agar slants (Oxoid, Basingstoke, UK), ${ }^{23}$ lysine decarboxylase test using lysine decarboxylase broth, methyl red VogesProskauer broth, Simmons citrate agar, sulfide indole motility medium (SIM), and indole and urease tests using urea broth (HiMedia, Mumbai, India) according to the procedures describe by Quinn et al. ${ }^{22}$

\section{Antimicrobial-Sensitivity Tests}

Antimicrobial susceptibility of the Salmonella isolates was conducted using standard Kirby-Bauer disk diffusion according to the guidelines of the Clinical Laboratory Standards Institute (CLSI). ${ }^{24} \mathrm{~A}$ bacterial suspension was prepared from a freshly grown colony in sterile nutrient broth, turbidity adjusted to $0.5 \mathrm{McF}$ arland standard, and the suspension spread carefully over a Müller-Hinton agar plate using a sterile cotton swab. Eleven antimicrobials commonly used in poultry practices and treatment of human cases of salmonellosis were used for this assay (Table 1). The medium containing the bacterial suspension and the antimicrobial disks were incubated aerobically at $37^{\circ} \mathrm{C}$ for $18-24$ hours. The zone of inhibition around each antimicrobial disk was measured using a transparent ruler. The results were interpreted as sensitive, intermediate, or resistant based on the diameter of zone of inhibition as described by the CLSI ${ }^{24}$ and are presented in Table 1.

\section{Data Management and Analysis}

Descriptive statistics are used to describe the prevalence of Salmonella. The effects of various risk factors on the isolation of Salmonella were analyzed by logistic regression in $\mathrm{R}$ software and the strength of associations expressed using ORs and 95\% CIs. $P<0.05$ was used to identify significant statistical associations.

\section{Results}

\section{Prevalence of Salmonella}

Salmonella was isolated from 131 (24.30\%, 95\% CI 20.74\%$28.15 \%$ ) of the 539 samples tested. Salmonella was found in 51 of the 250 samples collected from Bishoftu (20.40\%, 95\% CI $15.58 \%-25.93 \%$ ) and 76 of the 289 samples collected from Modjo (26.29\%, 95\% CI $21.32 \%-31.77 \%$ ). 
Table I Antimicrobials used for assessment of sensitivity profiles of Salmonella isolates and classification of sensitivity patterns

\begin{tabular}{|l|l|l|l|}
\hline & Resistance $\mathbf{( m m})$ & Intermediate $\mathbf{( m m})$ & Susceptible $\mathbf{( m m})$ \\
\hline Gentamicin $(10 \mu \mathrm{g})$ & $\leq 12$ & $12-15$ & $\geq 15$ \\
Erythromycin $(15 \mu \mathrm{g})$ & $\leq 13$ & $13-18$ & $\geq 18$ \\
Streptomycin $(10 \mu \mathrm{g})$ & $\leq 11$ & $11-15$ & $\geq 15$ \\
Chloramphenicol $(30 \mu \mathrm{g})$ & $\leq 12$ & $12-18$ & $\geq 18$ \\
Sulfamethazole-trimethoprim $(25 \mu \mathrm{g})$ & $\leq 10$ & $10-16$ & $\geq 16$ \\
Tetracycline $(10 \mu \mathrm{g})$ & $\leq 14$ & $14-19$ & $\geq 19$ \\
Ampicillin $(10 \mu \mathrm{g})$ & $\leq 13$ & $13-17$ & $\geq 17$ \\
Cloxaciline $(5 \mu \mathrm{g})$ & $\leq 10$ & $11-12$ & $\geq 13$ \\
Naldixic acid (30 $\mu \mathrm{g})$ & $\leq 13$ & $14-18$ & $\geq 19$ \\
Amoxicillin $(25 \mu \mathrm{g})$ & $\leq 13$ & $14-17$ & $\geq 17$ \\
Kanamycin $(30 \mu \mathrm{g})$ & $\leq 13$ & $14-17$ & $\geq 18$ \\
\hline
\end{tabular}

Salmonella spp. were isolated from $26.46 \%$ of the cloacal samples, $21.00 \%$ of the cecal contents, $30.77 \%$ of the feed samples, $25.00 \%$ of the water samples, $22.22 \%$ of samples from feed troughs, and $20.00 \%$ of samples from water troughs. At the farm level, $19.20 \%(95 \%$ CI $12.71 \%-$ $27.21 \%$ ), $24.80 \%$ (95\% CI $17.51 \%-33.32 \%$ ), $27.08 \%$ (95\% CI $20.02 \%-35.11 \%)$, and $25.52 \%$ (95\% CI $18.65 \%-33.42 \%)$ of the samples collected from B1, B2, M1, and M2, respectively, gave positive results for Salmonella (Table 2).

Salmonella spp. were isolated from a higher proportion of samples collected from chickens aged 31-40 days $(28.47 \%)$ than samples collected from younger chickens $(20.00 \%)$ and those older than 40 days. Higher proportions of samples collected from Cobb 500 (28.57\%) and Hubbard classic $(28.47 \%)$ breeds demonstrated positive results for Salmonella than those collected from Ross 308 $(13.33 \%)$ chickens. The prevalence of Salmonella isolation was higher in tank-water samples (27.27\%) than samples of tape water $(21.92 \%)$. However, none of the variables considered was statistically significantly associated with prevalence of Salmonella spp. Details of the distribution of Salmonella spp. in the samples are given in Table 3.

\section{Antimicrobial-Susceptibility Profiles}

A total of 99 Salmonella isolates were randomly selected and tested for their antimicrobial susceptibility. The highest level of resistance $(80.81 \%)$ was observed against tetracycline, followed by kanamycin $(71.72 \%)$, chloramphenicol and amoxicillin (67.68\%), sulfamethazole-trimethoprim (61.62\%), naldixic acid (63.64\%), and streptomycin $(59.60 \%)$, and most of the isolates were susceptible to gentamicin $(69.70 \%$, Table 4). From the 99 Salmonella isolates tested, 55 were resistant to two to five antimicrobials, 14 resistant to six to seven, and three

Table 2 Prevalence of Salmonella isolated from each sample collected from selected study farms

\begin{tabular}{|c|c|c|c|c|}
\hline Sample type & Tested, $\mathbf{n}$ & Salmonella ${ }^{+}$ & Prevalence & $95 \% \mathrm{CI}$ \\
\hline Cloacal swab & 189 & 50 & $26.46 \%$ & $20.32 \%-33.35 \%$ \\
\hline Cecum content & 100 & 21 & $21.00 \%$ & $13.49 \%-30.29 \%$ \\
\hline Feed & 52 & 16 & $30.77 \%$ & $18.72 \%-45.10 \%$ \\
\hline Water & 48 & 12 & $25.00 \%$ & 13.64\%-39.59\% \\
\hline Water trough & 60 & 12 & $20.00 \%$ & $10.78 \%-32.33 \%$ \\
\hline Feed trough & 90 & 20 & $22.22 \%$ & $14.13 \%-32.21 \%$ \\
\hline \multicolumn{5}{|l|}{ Farm } \\
\hline BI & 125 & 24 & $19.20 \%$ & $12.71 \%-27.21 \%$ \\
\hline B2 & 125 & 31 & $24.80 \%$ & $17.51 \%-33.32 \%$ \\
\hline MI & 144 & 39 & $27.08 \%$ & $20.02 \%-35.11 \%$ \\
\hline M2 & 145 & 37 & $25.52 \%$ & $18.65 \%-33.42 \%$ \\
\hline Total & 539 & $13 \mid$ & $24.30 \%$ & $20.74 \%-28.15 \%$ \\
\hline
\end{tabular}


Table 3 Proportion of samples yielding positive results for Salmonella by risk factor

\begin{tabular}{|c|c|c|c|c|c|c|c|}
\hline & & Tested, $\mathbf{n}$ & Salmonella ${ }^{+}$ & Prevalence & OR & $95 \% \mathrm{Cl}$ & $P$ \\
\hline Age (days) & $\begin{array}{l}2 I-30 \\
3 I-40 \\
4 I-45\end{array}$ & $\begin{array}{l}95 \\
144 \\
50\end{array}$ & $\begin{array}{l}19 \\
41 \\
11\end{array}$ & $\begin{array}{l}20.00 \% \\
28.47 \% \\
22.00 \%\end{array}$ & 0.565 & $0.14-3.33$ & 0.429 \\
\hline Breed & $\begin{array}{l}\text { Ross } 308 \\
\text { Hubbard classic } \\
\text { Cobb } 500\end{array}$ & $\begin{array}{l}75 \\
144 \\
70\end{array}$ & $\begin{array}{l}10 \\
41 \\
20\end{array}$ & $\begin{array}{l}13.33 \% \\
28.47 \% \\
28.57 \%\end{array}$ & 0.903 & $0.24-3.48$ & 0.881 \\
\hline Source of water & $\begin{array}{l}\text { Tap } \\
\text { Tank }\end{array}$ & $\begin{array}{l}146 \\
143\end{array}$ & $\begin{array}{l}32 \\
39\end{array}$ & $\begin{array}{l}21.92 \% \\
27.27 \%\end{array}$ & 1.472 & $0.65-3.39$ & 0.358 \\
\hline Type of house & $\begin{array}{l}\text { Hoop } \\
\text { Cement block }\end{array}$ & $\begin{array}{l}194 \\
95\end{array}$ & $\begin{array}{l}45 \\
26\end{array}$ & $\begin{array}{l}23.20 \% \\
27.37 \%\end{array}$ & 0.375 & $0.03-3.84$ & 0.412 \\
\hline Farm location & $\begin{array}{l}\text { Residential compound } \\
\text { Separate }\end{array}$ & $\begin{array}{l}145 \\
144\end{array}$ & $\begin{array}{l}41 \\
30\end{array}$ & $\begin{array}{l}28.28 \% \\
20.83 \%\end{array}$ & 0.650 & $0.23-0.39$ & 0.264 \\
\hline Type of sample & $\begin{array}{l}\text { Cloacal swab } \\
\text { Cecum content } \\
\text { Feed } \\
\text { Water }\end{array}$ & $\begin{array}{l}189 \\
100 \\
52 \\
48\end{array}$ & $\begin{array}{l}50 \\
21 \\
16 \\
12\end{array}$ & $\begin{array}{l}26.46 \% \\
21.00 \% \\
30.77 \% \\
25.00 \%\end{array}$ & 3.268 & $0.4 I-29.10$ & 0.272 \\
\hline
\end{tabular}

resistant to eight to ten antimicrobials. Intermediate resistance was observed against all antimicrobials tested, ranging from $16.16 \%$ for tetracycline to $35.35 \%$ for erythromycin.

\section{Discussion}

Broiler-meat production remains an important economic activity with huge potential for achieving food and nutrition security. However, in the absence of regular monitoring and surveillance, it can be a source of zoonotic pathogens. This study revealed the widespread occurrence of Salmonella in broilers, their inputs, and environs in smallhold farms in Bishoftu and Modjo. This indicates widespread occurrence of Salmonella along the broiler value chain. Chico Meat is distributing broiler meat to various parts of Ethiopia. Without appropriate supervision and intervention, this has important implications for public health. The widespread occurrence of Salmonella in all samples tested (water, feed, cloacal swabs, water and feed troughs, and cecal contents) coupled with the lack of knowledge about the role of biosecurity could have contributed to the transmission of the bacteria among flocks and probably among the farms. This is evident by the fact that the smallhold broiler farmers included in this study share farm implements and other inputs among themselves. The hygienic status of the farms studied was

Table 4 Antimicrobial-sensitivity profiles of Salmonella isolated

\begin{tabular}{|l|l|l|l|}
\hline & Resistance (\%) & Intermediate (\%) & Susceptible (\%) \\
\hline Gentamicin $(10 \mu \mathrm{g})$ & $10(10.10)$ & $20(20.20)$ & $69(69.70)$ \\
Erythromycin $(15 \mu \mathrm{g})$ & $24(24.24)$ & $35(35.35)$ & $40(40.4 \mathrm{I})$ \\
Streptomycin $(10 \mu \mathrm{g})$ & $59(59.60)$ & $24(24.24)$ & $16(16.16)$ \\
Chloramphenicol $(30 \mu \mathrm{g})$ & $67(67.68)$ & $17(17.17)$ & $15(15.15)$ \\
Sulfamethazole-trimethoprim $(25 \mu \mathrm{g})$ & $61(61.62)$ & $22(22.22)$ & $16(16.16)$ \\
Tetracycline $(10 \mu \mathrm{g})$ & $80(80.8 \mathrm{I})$ & $16(16.16)$ & $3(3.03)$ \\
Ampicillin $(10 \mu \mathrm{g})$ & $54(54.55)$ & $23(23.23)$ & $22(22.22)$ \\
Cloxacilline $(5 \mu \mathrm{g})$ & $29(29.29)$ & $27(27.27)$ & $43(43.44)$ \\
Naldixic acid $(30 \mu \mathrm{g})$ & $63(63.64)$ & $23(23.23)$ & $13(13.13)$ \\
Amoxicillin $(25 \mu \mathrm{g})$ & $67(67.68)$ & $19(19.19)$ & $13(13.13)$ \\
Kanamycin $(30 \mu \mathrm{g})$ & $71(71.72)$ & $18(18.18)$ & $10(18.18)$ \\
\hline
\end{tabular}


also poor and could be one of the factors that contributed to increased risk of contamination by Salmonella. The use of unclean feeding materials and unhygienic houses have been shown to be sources of contamination by Salmonella in poultry. ${ }^{25}$

The overall proportion of samples yielding Salmonella in this study is comparable to reports of $23.2 \%$ in cloacal swabs from Asossa and Bambasi ${ }^{26}$ and the $28 \%$ in fecal samples collected from broilers from Senegal. ${ }^{27}$ However, our observation is higher than most previous studies conducted in Ethiopia, including Ali et $\mathrm{al}^{9}$ from Bishoftu and Modjo, Abunna et $\mathrm{al}^{28}$ from Modjo, Aragaw et $\mathrm{al}^{29}$ from Hawassa, Abdi et $\mathrm{al}^{30}$ from central and southern Ethiopia, and Bekele and Ashenafi ${ }^{31}$ from Addis Ababa. Our findings are lower than the results of some studies carried out in Ethiopia and elsewhere in the world. For instance, higher proportions than ours were reported in chicken from Jimma, western Ethiopia. ${ }^{32}$ Similarly, higher proportions of Salmonella-positive samples were reported by van den Gissen et $\mathrm{al}^{33}$ in the Netherlands, Khan et $\mathrm{al}^{4}$ in Trindad, and Ishihara et $\mathrm{al}^{34}$ in Japan. The differences observed in the proportion of samples yielding Salmonella between our study and others could be due to differences in the isolation techniques used, geographical locations, biosecurity measures adopted, breeds studied, and husbandry practices used.

A relatively higher proportion of samples from Modjo were positive for Salmonella than Bishoftu, although the difference was not statistically significant. This could be due to differences in poultry management among owners from Modjo and Bishoftu. Broiler farmers in Bishoftu have training and experience from other poultry farmers, since commercial poultry farms have long been established in the town, while most smallhold broiler farmers in Modjo have taken up the business recently and lack experience and training. Previous studies have also revealed that poor and faulty management, particularly poor biosecurity practices, are associated with occurrence of Salmonella on broiler farms. ${ }^{35,36}$

According to the results of this study, a higher proportion of older broiler chickens carry Salmonella than chicks, suggesting the chance of getting Salmonella from the environment increases with age, sonsistent with earlier studies, ${ }^{37}$ but contradicting Ansari-Lari et al, ${ }^{38}$ who reported higher prevalence of Salmonella in young chicks. A difference in the proportion of samples yielding positive results was observed between housing types for the broilers, though not statistically significant. It was higher in cement ones than those constructed from round wire. This could be due to the possibility of accumulation of waste and leftover feed and water on the floor. Since the cement blocks do not allow circulation of sufficient air, water and waste materials excreted from the chickens create wetness on the floor, which is conducive for the multiplication and survival of Salmonella. In contrast, the wire mesh allows the circulation of air, reducing humidity and the risk of Salmonella. The effects of housing type on the occurrence of Salmonella in poultry have been documented elsewhere. $^{39}$

Sensitivity profiles of eleven antimicrobials were tested. We suggest gentamicin is the most promising drug to treat infections with Salmonella. Most of the other antimicrobials were losing efficacy due to emergence of resistance, while some were found to be in a transitional phase. The Salmonella isolates tested were resistant to the commonly used antimicrobials in poultry practices (tetracycline, kanamycin, amoxicillin, chloramphenicol, nalidixic acid, and sulfadimethoxine-trimethoprim). The antimicrobials tested are found at all veterinary-drug vendors and on all farms. Their use has not been based on the prescription of veterinarians. They are used indiscriminately by farm owners and attendants whenever any sign of illness is detected. In addition, feed processors include some antimicrobials as growth promoters. The indiscriminate use of these drugs could have contributed to the emergence of resistance in the Salmonella isolates. These drugs are also used widely in medical practices to treat infections with Salmonella. The occurrence of resistance against these drugs has important public health implications. Resistance against kanamycin, sulfadimethoxine-trimethoprim, tetracycline, nalidixic acid, and chloramphenicol reported in this study is consistent with others. $^{40,41}$ Antimicrobial resistance in Salmonella isolated from various livestock and products have been reported in Ethiopia $^{15,16,42,43}$ and elsewhere in the world, ${ }^{44}$ suggesting the global occurrence of resistance. Continued use of the same antimicrobials could exert selection pressure on resistant bacteria, favoring their global distribution. The presence of widespread antimicrobial resistance can adversely affect public health, as treatment of illness caused by Salmonella becomes difficult.

In conclusion, this study revealed that Salmonella occurs widely in broilers, inputs, and the environment on smallhold farms. The Salmonella isolates obtained in this study were resistant to tetracycline, kanamycin, chloramphenicol, amoxicillin, sulfamethazole-trimethoprim, 
naldixic acid, and streptomycin. The emergence of resistance to various antibiotics commonly used in medical and poultry practices have important implications for public health.

\section{Data Sharing Statement}

The data collected and used to support this article can be requested from the first or corresponding author.

\section{Ethics Approval and Consent to Participate}

Ethics approval was obtained from the Ethics Review Committee of the College of Veterinary Medicine and Agriculture, Addis Ababa University (VM/ERC/16/05/ 13/2021). The Chico Meat abattoir and the owners of the smallhold broiler farms that were included in this study were informed about the purpose of the study, and the consent of each was obtained.

\section{Acknowledgments}

Addis Ababa University thematic project VPRTT/LT-497/ 2019 is highly acknowledged for the financial support provided. Heartfelt gratitude also goes to Jacab Henndriksen, Jacob Dekker, and Chico Meat for their friendly approach and kind support provided during the study. Muuken Tekle is highly acknowledged for his unreserved support during laboratory analysis of the samples.

\section{Author Contributions}

All authors made a significant contribution to the activities accomplished for the publication of this article and contributed to study conception, design, and execution, collection of samples, laboratory analysis and interpretation, drafting and editing of the paper, agreed on the journal to which the article was submitted, gave final approval to the version to be published, and agree to be accountable for all aspects of the work.

\section{Funding}

This study was funded by Addis Ababa University through thematic project VPRTT/LT-497/2019, which provided full financial support.

\section{Disclosure}

The authors declare that they have no conflicts of interest for this work.

\section{References}

1. Maqsood A. Salmonella Prevalence in the Poultry Feed Industry in Pakistan [MSc Thesis]. Swedish University of Agricultural Sciences, Faculty of Veterinary Medicine and Animal Science; 2012:1.

2. Abie G, Eguale T, Ademe M, et al. Fowl typhoid: a repeated attack in Jimma agricultural college poultry farm. Proceedings of the 17th Annual Conference of the Ethiopian Veterinary Association (EVA), Held in Addis Ababa, Ethiopia; 2003:101-107.

3. Ejo M, Garedew L, Alebachew Z, et al. Prevalence and antimicrobial resistance of Salmonella isolated from animal-origin food items in Gondar, Ethiopia. Bio Med Res Int. 2016;2016. doi:10.1155/2016/ 4290506

4. Khan AS, Georges K, Rahaman S, et al. Prevalence and serotypes of Salmonella spp. on chickens sold at retail outlets in Trinidad. PLoS One. 2018;13(8):e0202108. doi:10.1371/journal.pone.0202108

5. Pulido-Landínez M. Food safety - Salmonella update in broilers. Anim Feed Sci Technol. 2019;250:53-58. doi:10.1016/j. anifeedsci.2019.01.008

6. Antunes P, Mourão J, Campos J, Peixe L. Salmonellosis: the role of poultry meat. Clin Microbiol Infect. 2016;22(2):110-121. doi:10.1016/j.cmi.2015.12.004

7. Qamar A, Ismail T, Akhtar S, Farooq S. Prevalence and antibiotic resistance of Salmonella spp. in South Punjab-Pakistan. PLoS One. 2020;15(11):e0232382. doi:10.1371/journal.pone.0232382

8. Adzitey REF, Huda N. Prevalence of resistant Salmonella spp. isolated from raw meat and liver of cattle in the Wa Municipality of Ghana. IOP Conf Ser Earth Environ Sci. 2019;287:012006. doi:10.1088/1755-1315/287/1/01200

9. Ali DA, Tadesse B, Ebabau A. Prevalence and antibiotic resistance pattern of salmonella isolated from caecal contents of exotic chicken in Debre Zeit and Modjo, Ethiopia. Int J Microbiol. 2020;2020. doi:10.1155/2020/1910630

10. Guerra B, Soto S, Helmuth R, et al. Characterization of a self-transferable plasmid from Salmonella enterica serotype typhimurium clinical isolates carrying two integron-borne gene cassettes together with virulence and drug resistance genes. Antimicrob Agents Chemother. 2002;46(9):2977-2981. doi:10.1128/AAC.46.9.2977-2981.2002

11. Bada-Alambedji R, Fofana A, Seydi M, et al. Antimicrobial resistance of Salmonella isolated from poultry carcasses in Dakar (Senegal). Braz J Microbiol. 2006;37(4):510-515. doi:10.1590/ S1517-83822006000400020

12. Gezahegn A, Rich KM. Poultry value chains and HPAI in Ethiopia. Working Paper; Africa. Indonesia Team Working Paper 25. Washington, DC, USA; 2010.

13. Abebe E, Gugsa G, Ahmed M. Review on major food-borne zoonotic bacterial pathogens. J Trop Med. 2020;3:1-19. doi:10.1155/2020/ 4674235

14. Woldemariam E, Molla B, Alemayehu D, et al. Prevalence and distribution of Salmonella in apparently healthy slaughtered sheep and goats in Debre Zeit, Ethiopia. Small Rumin Res. 2005;58 (1):19-24. doi:10.1016/j.smallrumres.2004.08.008

15. Geresu MA, Desta WZ. Carriage, risk factors, and antimicrobial resistance patterns of Salmonella isolates from raw beef in Jimma, Southwestern Ethiopia. Infect Drug Resist. 2021;2021:2349-2360. doi:10.2147/IDR.S313485

16. Addis Z, Kebede N, Worku Z, et al. Prevalence and antimicrobial resistance of Salmonella isolated from lactating cows and in contact humans in dairy farms of Addis Ababa: a cross sectional study. $B M C$ Infect Dis. 2011;11:222. doi:10.1186/1471-2334-11-222

17. Conway A. Meat production: poultry meat production up 13 million metric tons by 2026 . Global meat production by species. Poultry Trends. 2017;2017:22-23.

18. Meteab BK, Abed AAA. Isolation and identification of Salmonella serotypes in poultry. Al-Qadisiyah J Vet Med Sci. 2018;17(1):75-80. doi:10.29079/vol17iss1 art480 
19. International Organization for Standardization (ISO). ISO 6579:2002/ Amd 1:2007. Detection of Salmonella spp. In Animal Faeces and in Environmental Samples from the Primary Production Stage, Amendment 1, Annex D. In: Microbiology of Food and Animal Feeding Stuffs. Horizontal Method for the Detection of Salmonella Spp. Geneva, Switzerland: International Organization for Standardization; 2007.

20. Kim H, Bhunia AK. SEL, a selective enrichment broth for simultaneous growth of Salmonella enterica, Escherichia coli O157: H7, and Listeria monocytogenes. Appl Environ Microbiol. 2008;74 (15):4853-4866. doi:10.1128/AEM.02756-07

21. Hammack TS, Amaguaña RM, Andrews WH. Rappaport-vassiliadis medium for recovery of Salmonella spp. from low microbial load foods: Collaborative study. J AOAC Int. 2001;84(1):65-84. doi:10.1093/jaoac/84.1.65

22. Quinn PJ, Markey BK, Leonard FC, et al. Veterinary Microbiology and Microbial Disease. 2nd ed. 9600 Carrington Road, Oxford, OX4 200 UK: Blackwell Science Ltd; 2011:263-286.

23. Andrews WH, Jacobson HWA, Zhang BGG, et al. Bacteriological Analytical Manual (BAM) Chapter 5: Salmonella. 8th ed. US Food and Drug Administration; 2021.

24. CLSI. Clinical and Laboratory Standards Institute. Performance Standards for Antimicrobial Susceptibility Testing: Twenty-Third Informational Supplement M100-S23. Wayne, PA, USA: CLSI; 2013.

25. Davies RH, Hinton MH. Investigations into Salmonella contamination in poultry feed mills in the United Kingdom. $J$ Appl Microbiol. 2010:364-5072. doi:10.1111/j.1365-2672.2010.04767.x

26. Asmamaw AJ, Yami B, Gebrehiwet W. Isolation, identification and antimicrobial resistance profile of salmonella isolated from chicken cloacal swab in Asossa and Bambasi Town, Benishangul Gumuz Regional State. Biomed Nurs. 2018;4(4):70-91. doi:10.7537/ marsbnj040418.10

27. Cardinale E, Tall F, Gueye EF, et al. Risk factors for Salmonella enterica subsp. enterica infection in senegalese broiler-chicken flocks. Prev Vet Med. 2004;63(3-4):151-161. doi:10.1016/j. prevetmed.2004.03.002

28. Abunna F, Bedasa M, Beyene T, et al. Salmonella: isolation and antimicrobial susceptibility tests on isolates collected from poultry farms in and around Modjo, Central Oromia, and Ethiopia. J Anim Poult Sci. 2016;5(2):21-35.

29. Aragaw K, Terefe L, Abera M. Prevalence of Salmonella infection in intensive poultry farms in Hawassa and isolation of Salmonella species from sick and dead chickens. Ethiop Vet J. 2010;14 (2):115-124. doi:10.4314/evj.v14i2.63888

30. Abdi RD, Mengstie F, Beyi AF, et al. Determination of the sources and antimicrobial resistance patterns of Salmonella isolated from the poultry industry in Southern Ethiopia. BMC Infect Dis. 2017;17 (1):352. doi:10.1186/s12879-017-2437-2

31. Bekele B, Ashenafi M. Distribution of drug resistance among enterococci and Salmonella from poultry and cattle in Ethiopia. Trop Anim Health Prod. 2010;42(5):857-864. doi:10.1007/s11250-009-9499-0
32. Kindu A, Addis M. A survey on Salmonella infection among chicken flocks in Jimma town, Ethiopia. Afr J Microbiol Res. 2013;7 (14):1239-1245. doi:10.5897/AJMR12.1429

33. Van de Giessen AW, Bouwknegt M, Dam-Deisz WDC, et al. Surveillance of Salmonella spp. and Campylobacter spp. in poultry production flocks in the Netherlands. Epidemiol Infect. 2006;134 (6):1266-1275. doi:10.1017/S0950268806005905

34. Ishihara K, Takahashi T, Morioka A, et al. National surveillance of Salmonella enterica in food-producing animals in Japan. Acta Vet Scand. 2009;51(35). doi:10.1186/1751-0147-51-35

35. Liljebjelke KA, Hofacre CL, Liu T, et al. Vertical and horizontal transmission of Salmonella within integrated broiler production system. Foodborne Pathog Dis. 2005;2(1):90-102. doi:10.1089/ fpd.2005.2.90

36. Huneau-Salaün A, Marianne C, Françoise L, et al. Risk factors for Salmonella enterica subsp. enterica contamination in 519 French laying hen flocks at the end of the laying period. Prev Vet Med. 2009;89(1-2):51-58. doi:10.1016/j.prevetmed.2009.01.006

37. Mahmud S, Bari L, Hossain MA. Prevalence of Salmonella serovars and antimicrobial resistance profiles in poultry of Savar Area, Bangladesh. Foodborne Pathog Dis. 2011;8(10):1111-1118. doi:10.1089/fpd.2011.0917

38. Ansari-Lari M, Shekarforoush S, Mehrshad S. Prevalence and risk factors for Salmonella spp. colonization in broiler flocks in Shiraz, southern Iran. Vet Res Forum. 2014;5(1):65-68. PMID: 25568695 PMCID: PMC4279663.

39. Van Hoorebeke S, Van Immerseel F, Haesebrouck F, et al. The influence of the housing system on Salmonella infections in laying hens: a review. Zoonoses Public Health. 2011;58:304-311. doi:10.1111/j.1863-2378.2010.01372.x

40. Fisseha M. Salmonella Isolates and Drug Resistance Epidemiology in Poultry Related Samples in Selected Sites of Central and South Ethiopia [MSc Thesis]. College of Veterinary Medicine and Agriculture, Addis Ababa University; 2015. Available from: http:// etd.aau.edu.et/handle/123456789/21864. Accessed July 24, 2021.

41. Su L, Chiu C, Chu C, et al. Antimicrobial resistance in nontyphoid Salmonella serotypes: a global challenge. Clin Infect Dis. 2004;39 (4):546-551. doi:10.1086/422726

42. Zewdu E, Cornelius P. Antimicrobial resistance pattern of Salmonella serotypes isolated from food items and personnel in Addis Ababa, Ethiopia. Trop Anim Health Prod. 2009;41(2):241-249. doi:10.1007/ s11250-008-9181-y

43. Gebremedhin EZ, Soboka GT, Borana BM, et al. Prevalence, risk factors, and antibiogram of nontyphoidal Salmonella from beef in Ambo and Holeta Towns, Oromia Region, Ethiopia. Int J Microbiol. 2020;2021. doi:10.1155/2021/6626373

44. Poppe C, Ayroud M, Ollis G, et al. Trends in antimicrobial resistance of salmonella isolated from animals, foods of animal origin, and the environment of animal production in Canada, 1994-1997. Microb Drug Resist. 2004;7:197-212. doi:10.1089/10766290152045084
Infection and Drug Resistance

\section{Publish your work in this journal}

Infection and Drug Resistance is an international, peer-reviewed openaccess journal that focuses on the optimal treatment of infection (bacterial, fungal and viral) and the development and institution of preventive strategies to minimize the development and spread of resistance. The journal is specifically concerned with the epidemiology of antibiotic resistance and the mechanisms of resistance development and diffusion in both hospitals and the community. The manuscript management system is completely online and includes a very quick and fair peerreview system, which is all easy to use. Visit http://www.dovepress.com/ testimonials.php to read real quotes from published authors. 